\title{
Epidemiological Investigation of Crimean-Congo Hemorrhagic Fever infection in Cattle in some provinces of Turkey
}

\author{
Murat Şevik \\ Department of Virology, Faculty of Veterinary Medicine, Mustafa Kemal University, Hatay, Turkey
}

Geliş Tarihi / Received: 18.01.2018, Kabul Tarihi / Accepted: 06.05.2018

\begin{abstract}
Crimean-Congo hemorrhagic fever (CCHF) is a zoonotic disease which causes lethal hemorrhagic fever in humans. The purpose of this study was to investigate the CCHF infection status in cattle in the Central Anatolia region and the central-west part of the Aegean region of Turkey. For this purpose, EDTA whole blood $(n=329)$ and sera $(n$ $=329$ ) samples were obtained from epidemiologically independent herds $(n=94)$ during the months of March 2016 and September 2017. The exposure status to CCHF was determined using ELISA for detection of CCHF virus (CCHFV) specific IgG antibodies in cattle sera samples. Real-time reverse-transcriptase PCR was used to detect viral RNA in EDTA whole blood samples. The CCHFV-specific IgG antibodies were detected in 4 out of 329 animals, accounting for $1.2 \%$ prevalence rate. CCHFV RNA was not detected in EDTA whole blood samples. The low seroprevalence suggests only sporadic introduction of CCHFV. Further epidemiological studies are needed to determine the distribution of CCHFV infection in livestock in Turkey.
\end{abstract}

Key words: Crimean-Congo hemorrhagic fever, Epidemiology, Turkey, Cattle, ELISA, Real-time RT-PCR

\section{Türkiye’nin bazı İllerindeki Sı̆̆ırlarda Kırım Kongo Kanamalı Ateş Enfeksiyonunun Epidemiyolojik Araştırılması}

\begin{abstract}
Özet: Kırım-Kongo Kanamalı Ateşi (KKKA) insanlarda öldürücü hemorajik ateşe neden olan zoonotik bir hastalıktır. Bu çalışmanın amacı Türkiye'nin İç Anadolu ve Orta Batı Ege Bölgelerindeki sığırlarda KKKA enfeksiyon durumunu araştırmaktı. Bu amaçla Mart 2016 ve Eylül 2017 tarihleri arasında epidemiyolojik olarak birbirinden bağımsız işletmelerden $(n=94)$ EDTA'lı tam kan $(n=329)$ ve serum $(n=329)$ örnekleri topland1. KKKA'ne maruziyet durumu, sığır serum örneklerinde KKKA virusuna (KKKAV) spesifik $\operatorname{lgG}$ antikorlarının ELISA ile tespit edilmesi ile belirlenmiştir. Real time reverse transkripsiyon PCR yöntemi, EDTA'lı tam kan örneklerinde viral RNA varlığını tespit etmek için kullanılmıştır. Üç yüz yirmi dokuz hayvanın, dördünde KKKAV spesifik $\operatorname{lgG}$ antikoru tespit edildi ve \%1.2 prevalans oranı hesaplandı. EDTA'lı tam kan örneklerinde KKKAV RNA'sı tespit edilememiştir. Düşük seroprevelans oranı sporadik KKKAV vakalarının olduğunu düşündürmektedir. Türkiye'deki çiftlik hayvanlarında KKKAV enfeksiyonunun dağılımını tespit etmek için daha fazla epidemiyolojik çalışmalara ihtiyaç vardır.
\end{abstract}

Anahtar kelimler: Kırım Kongo Kanamalı Ateşi, Epidemiyoloji, Türkiye, Sığır, ELISA, Real-time RT-PCR

\section{Introduction}

Crimean-Congo hemorrhagic fever (CCHF) is a tick-borne zoonotic disease that can cause serious hemorrhagic disease in humans. CCHF is characterised by fever, weakness, myalgia and hemorrhagic signs with case fatality rates ranging from $5 \%$ to $80 \%[5,37,39]$. Crimean-Congo hemorrhagic fever virus (CCHFV), the causative agent of CCHF, is a single-stranded RNA virus and belongs to the Nairovirus genus of the Bunyaviridae family [5].

CCHFV is primarily transmitted by Hyalomma spp. ticks [35]. The virus can also be transmitted horizontally and vertically within the tick popula- tion [11]. Wild (giraffe, rhinoceros, eland, kudu, buffalo and zebra) and domestic animals (cattle, sheep, goats, horses, donkeys and camels) can be infected and play a role in the spread of virus [25]. Viremia lasting up to 2 weeks can be observed in infected animals, but they do not show clinical signs. However, seroconversion can be observed in infected animals [30].

CCHFV infections have been reported in SubSaharan Africa, Asia, the Middle East and Southeastern Europe [5, 9, 13]. CCHF was first reported in the Tokat Province in Turkey in 2002, and more than 9700 human cases have been reported from 2002 to 2016 [19]. 
Detection of CCHFV-specific antibodies in the animal population especially cattle can successfully be used as indicator for the presence or absence of CCHFV in an area $[22,31,35]$. Because Hyalomma tick species, which are both vectors and reservoirs of CCHFV are generally found in cattle, but can also cause infestation in sheep and goats [15]. Information about CCHFV infection in animals in Turkey is very limited. Therefore, the aim of this study was to investigate the CCHFV infection status in cattle in Central Anatolia Region and centralwest part of the Aegean region of Turkey.

\section{Materials and Methods}

\section{Study Area}

This study was conducted during the months of March 2016 and September 2017 in the Afyonkarahisar Province in the central-west part of the Aegean region and in the Konya and Aksaray Provinces in the Central Anatolia region of Turkey (Fig. 1). These regions have continental climate characterised by hot and dry summer. The elevation of the
Afyonkarahisar, Konya and Aksaray Provinces are $1034 \mathrm{~m}, 1031 \mathrm{~m}$ and $980 \mathrm{~m}$, respectively. The annual rainfall in the studied provinces varies between $322 \mathrm{~mm}$ (Konya Province) and $439 \mathrm{~mm}$ (Afyonkarahisar Province) (Turkish State Meteorological Service). The number of herds in the Afyonkarahisar, Konya and Aksaray Provinces was 38993, 55565 and 17225, respectively (Turkish Statistical Institute, 2016).

\section{Sample collection}

EDTA whole blood $(n=329)$ and sera $(n=329)$ samples from cattle were collected from 94 epidemiologically independent herds in the Afyonkarahisar, Konya and Aksaray Provinces (Table 1). On average, three to four cattle per herds were sampled randomly. All samples were collected from cattle older than 12 months, which were grazing frequently on common pastures. No clinical signs of disease were observed in the sampled animals at the sampling time. Buffy coat cells were obtained from EDTA whole blood samples by centrifugation at $2200 \mathrm{rpm}$ for 10 minutes, and used for RNA extraction.

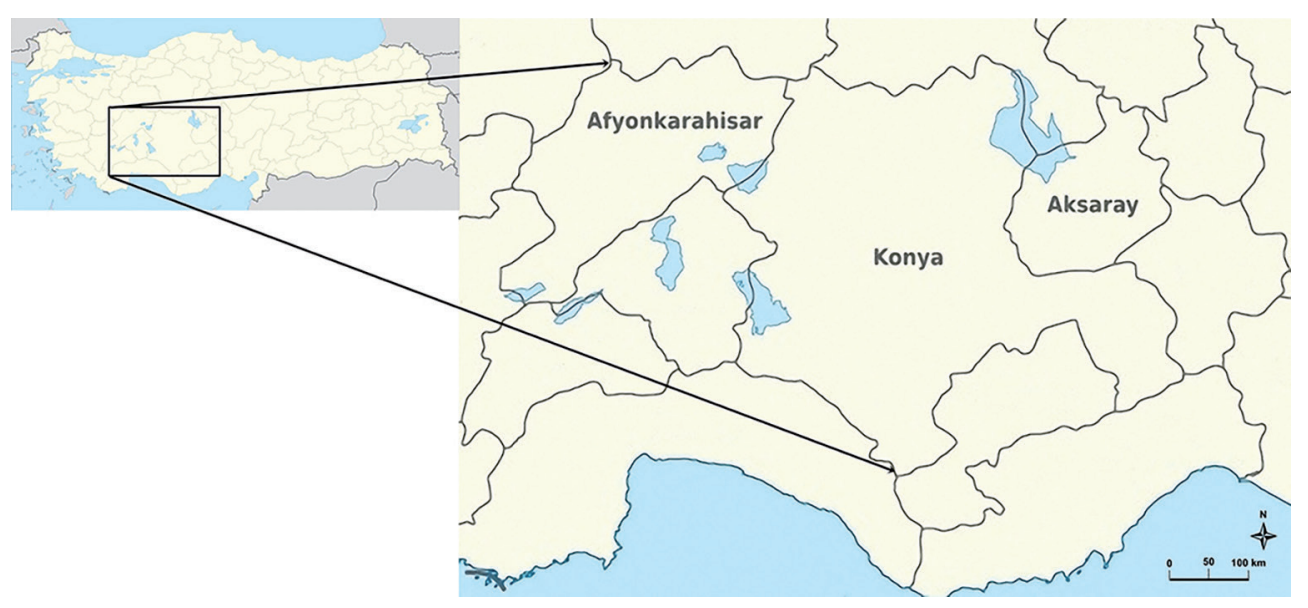

Figure 1. Location of investigated regions in Turkey.

\section{Serological analysis}

The CCHFV-specific IgG antibodies in the sera samples were detected using an adapted ELISA method with a commercial kit (Vectorbest, Novosibirsk, Russia) with modifications including the use of goat anti-bovine IgG-HRP conjugate (Southern Biotech, Birmingham, USA) $[23,28]$. The reported sensitivity and specificity of the adapted ELISA method were $98 \%$ and $99 \%$, respectively [23].
Sera samples were diluted 1:100 in dilution buffer (by manufacturer), and were incubated for $1 \mathrm{~h}$ at $37^{\circ} \mathrm{C}$. After the wash step, goat anti-bovine IgG-HRP conjugate (Southern Biotech, Birmingham, USA) diluted 1:6.000 in conjugate dilution buffer (by manufacturer) was added to each well. Tetramethylbenzidine (Sigma-aldrich, USA) solution was added to each well after incubation period of $30 \mathrm{~min}$ at $37^{\circ} \mathrm{C}$. The reaction was stopped with 
$\mathrm{H} 2 \mathrm{SO} 4$, and optical density of each well was read at $450 \mathrm{~nm}$ (reference wavelength $620 \mathrm{~nm}$ ) filter using a spectrophotometer (Bio-Tek Instruments Inc., Winooski, Vt.) All samples were run in duplicate.

\section{RNA extraction and real-time RT-PCR}

RNA extraction was carried out from the buffy coat cells from EDTA whole blood samples using QIAamp Cador Pathogen Mini Kit (Qiagen, Hilden, Germany). Real-time RT-PCR was performed with primers and probe designed by Wölfel et al. [36] that amplified nucleotides 181-bp region near the 5 '-end of the S segment of CCHFV. One step realtime RT-PCR was performed with the QuantiFast Probe RT-PCR plus Kit (Qiagen, Hilden, Germany). Amplification was carried out in a Rotor-Gene Q (Qiagen, Hilden, Germany) with the following conditions: reverse transcription step of $20 \mathrm{~min}$ at $50^{\circ} \mathrm{C}$ and $5 \mathrm{~min}$ at $95{ }^{\circ} \mathrm{C}$, followed by 45 cycles at $94{ }^{\circ} \mathrm{C}$ for $15 \mathrm{sec}, 59{ }^{\circ} \mathrm{C}$ for $30 \mathrm{sec}$. A set of synthetic oligonucleotides described by Atkinson et al. [3] was used as the positive control, whereas nuclease-free water was used as the negative control for the analyses. The optimization of the assay was carried out by using both positive and negative controls.

\section{Statistical analysis}

The confidence interval was calculated using GraphPad InStat version 3.10 (GraphPad Software, San Diego, CA, USA).

\section{Results}

\section{Seroepidemiological study}

The result of this study showed that 4 out of 329 sera samples were positive for CCHFV specific antibodies (1.2\% prevalence; 95\% CI: $0.4 \%-3.2 \%)$ (Table 1). Ages of the seropositive cattle were higher than 4 years old. On the province basis, the highest antibody prevalence (3.4\%) was found in the Afyonkarahisar Province whereas no CCHFVspecific antibodies were found in the cattle in the Konya and Aksaray Provinces (Table 1).

Table 1. The seroprevalence of CCHFV infection in the study area

\begin{tabular}{lccc}
\hline Province & No. examined herds & No. positive herds & CCHFV seroprevalence (\%) \\
\hline Afyonkarahisar & 35 & 2 & $3.4 \%(4 / 118)$ \\
Aksaray & 25 & - & $-(0 / 89)$ \\
Konya & 34 & - & $-(0 / 122)$ \\
Total & $\mathbf{9 4}$ & $\mathbf{2}$ & $\mathbf{1 . 2 \%}(\mathbf{4 / 3 2 9 )}$ \\
\hline
\end{tabular}

\section{Detection of CCHFV RNA by real-time RT-PCR}

CCHFV RNA was not detected in the buffy coat cells from EDTA whole blood samples.

\section{Discussion}

Crimean-Congo hemorrhagic fever has been reported in many regions of Asia, the Middle East, SubSaharan Africa and South-eastern Europe [5, 9, 13]. The endemic presence of CCHFV in Turkey has already been reported $[17,19,32]$.

The first CCHF cases were reported in Turkey in 2002, in the region of Tokat Province, which is located in northern Turkey. After the first cases, CCHF occurred in the regions of the Black Sea and northern parts of the Central Anatolia [19]. Furthermore, CCHFV infection has been report- ed in non-endemic areas of the Turkey [27, 33]. Afyonkarahisar, Konya and Aksaray Provinces are not located in endemic areas of the Turkey, but the presence of CCHFV infection in the Afyonkarahisar Province was confirmed by existence of clinical human cases in 2008 [34].

In Turkey, most of the studies were conducted to determine the presence of CCHFV in ticks $[1,12$, $26,32,38]$. There are no sufficient data concerning the animal infection with the CCHFV in Turkey. Detection of CCHFV specific immunoglobulins in domestic animals is important indicators for the circulation of CCHFV in a region and risk for human infection [29]. Furthermore, it has been reported that following infection CCHFV specific IgM titers decline to undetectable levels in about sixteen weeks, while $\operatorname{IgG}$ titers remain detectable for at 
least 5 years [21]. This study therefore investigated the prevalence of CCHFV-specific IgG antibodies in cattle. CCHFV infection status in cattle in Central Anatolia Region and central-west part of the Aegean region of Turkey has not been investigated to the best of found knowledge.

CCHFV specific antibodies were found in cattle in two herds in the Afyonkarahisar Province. No animals were tested positive for CCHFV-specific antibodies in the Konya and Aksaray Provinces. This result can be explained by the number of sampled cattle and the low seroprevalence of CCHF in these provinces. Furthermore, human CCHF cases were reported in the Afyonkarahisar Province whereas no human CCHF cases were reported in the Konya and Aksaray Provinces [34]. Previous studies have been reported a strong association between the appearance of human CCHF cases and seropositivity in the livestock [30].

In this study ages of the seropositive cattle were higher than 4 years old. This finding is consistent with the previous studies reported that probability of exposure of cattle to infected tick in the pasture increases with age $[4,10]$. In the present study, seropositive cattle were residing in two herds; it might be an isolated local CCHFV circulation in that area.

Reported seroprevalence of CCHFV in cattle were $1 \%$ in the Giza governorate in central Egypt [14], 4.74\% in 10 regions of Albania (Has, Kavaje, Kukes, Berat, Kolonje, Pogradec, Rreshen, Korce (Bulgarec/Qatrom) and Gjirokastra) [21], 6.7\% in the Maharashtra region of India [24], 6.8\% in the Southern Khorasan region of Iran [20], 13\% in the Marmara region of Turkey [33], 17.3\% in the Vardar region of Republic of Macedonia [23], 31\% in the Malishevë municipality in Kosovo [8] and $71 \%$ in the Aytos municipality in Bulgaria [4]. The result of this study showed that overall $1.2 \%(4 / 329)$ of the cattle was positive for $\lg \mathrm{G}$ antibodies to CCHFV. These different serological results can be explained by the competent vector distribution, host preference of tick vectors, climate and environmental changes, detection method, sample size and management conditions [16].

CCHFV infected animals do not show clinical signs but they have a viremic phase lasting up to 7-15 days [30, 35]. There have been few studies on the status of CCHFV infection in animals in Turkey [2, 18, 33]. Albayrak et al. [2] found CCHFV RNA in the blood of small ruminants in northern Turkey. A previous study has detected viral antigens in the blood of cattle in the Marmara region, a non-endemic region, of Turkey [33]. However, in this study CCHFV RNA was not detected in EDTA whole blood samples. This result suggests that sampled animals were not viremic at the time of sampling. It has also been suggested that there is no active circulation of the virus in the investigated regions. Members of the genus Hyalomma spp. ticks are the principal vectors of CCHFV [6]. Environmental factors such as temperature, humidity, precipitation and altitude have a significant effect on tick activities and can thus alter the incidences CCHFV infection [7]. Most of the CCHF cases have been reported in the northern part of the country and middle Black Sea region indicating that $\mathrm{CCHF}$ is endemic in that region of Turkey [17, 32]. Afyonkarahisar, Konya and Aksaray Provinces are not located in endemic areas of the Turkey. Thus, it can be speculated that environmental factors in the sampled area are not suitable for the spread of the CCHFV infection.

In conclusion, the results of this study indicate that seroprevalence of CCHFV was low in cattle in the investigated regions. Prevalence of CCHFV infection may change depending on the location of the prevalence study, and geographical and environmental factors that affect the abundance of tick population. Therefore, further epidemiological studies are needed to determine distribution of CCHFV in domestic animals in the whole country.

\section{References}

1. Albayrak H, Ozan E, Kurt M, (2010). An antigenic investigation of Crimean-Congo hemorrhagic fever virus (CCHFV) in hard ticks from provinces in northern Turkey. Trop Anim Health Prod. 42, 1323-1325.

2. Albayrak H, Ozan E, Kurt M, (2012). Serosurvey and molecular detection of Crimean-Congo hemorrhagic fever virus (CCHFV) in northern Turkey. Trop Anim Health Prod. 44, 1667-1671.

3. Atkinson B, Chamberlain J, Logue CH, Cook N, Bruce C, Dowall SD, Hewson R, (2012). Development of a real-time RT-PCR assay for the detection of Crimean-Congo hemorrhagic fever virus. Vector Borne Zoonotic Dis. 12, 786-793.

4. Barthel R, Mohareb E, Younan R, Gladnishka T, Kalvatchev N, Moemen A, Mansour SS, Rossi C, Schoepp R, Christova I, (2014). Seroprevalance of Crimean-Congo haemorrhagic 
fever in Bulgarian livestock. Biotechnol Biotechnol Equip. 28, 540-542.

5. Bente DA, Forrester NL, Watts DM, McAuley AJ, Whitehouse CA, Bray M, (2013). Crimean-Congo hemorrhagic fever: history, epidemiology, pathogenesis, clinical syndrome and genetic diversity. Antiviral Res. 100, 159-189.

6. Estrada-Peña A, Zatansever Z, Gargili A, Aktas M, Uzun R, Ergonul O, Jongejan F, (2007). Modeling the spatial distribution of crimean-congo hemorrhagic fever outbreaks in Turkey. Vector Borne Zoonotic Dis. 7, 667-678.

7. Estrada-Peña A, Ostfeld RS, Peterson AT, Poulin R, de la Fuente J, (2014). Effects of environmental change on zoonotic disease risk: an ecological primer. Trends Parasitol. 30, 205-214.

8. Fajs L, Humolli I, Saksida A, Knap N, Jelovšek M, Korva M, Dedushaj I, Avšič-Županc T, (2014). Prevalence of Crimean-Congo hemorrhagic fever virus in healthy population, livestock and ticks in Kosovo. PLoS One. 9:e110982.

9. Formenty P, Schnepf G, Gonzalez-Martin F, Bi Z, (2007). International Surveillance and Control of Crimean-Congo Hemorrhagic Fever Outbreaks. Ergonul O, Onder E, Whitehouse CA. eds. Crimean-Congo Hemorrhagic Fever: A Global Perspective. Dordrecht, Netherlands: Springer. p. 295-303.

10. Gergova I, Kunchev M, Kamarinchev B, (2012). CrimeanCongo hemorrhagic fever virus-tick survey in endemic areas in Bulgaria. J Med Virol. 84, 608-614.

11. Gonzalez JP, Camicas JL, Cornet JP, Faye O, Wilson ML, (1992). Sexual and transovarian transmission of CrimeanCongo haemorrhagic fever virus in Hyalomma truncatum ticks. Res Virol. 143, 23-28.

12. Gunes T, Poyraz O, Vatansever Z, (2011). Crimean-Congo hemorrhagic fever virus in ticks collected from humans, livestock, and picnic sites in the hyperendemic region of Turkey. Vector Borne Zoonotic Dis. 11, 1411-1416.

13. Hoogstraal H, (1979). The epidemiology of tick-borne Crimean-Congo hemorrhagic fever in Asia, Europe, and Africa. J Med Entomol. 15, 307-417.

14. Horton KC, Wasfy M, Samaha H, Abdel-Rahman B, Safwat S, Abdel Fadeel M, Mohareb E, Dueger E, (2014). Serosurvey for zoonotic viral and bacterial pathogens among slaughtered livestock in Egypt. Vector Borne Zoonotic Dis. 14, 633-639.

15. Ica A, Inci A, Vatansever Z, Karaer Z, (2007). Status of tick infestation of cattle in the Kayseri region of Turkey. Parasitol Res. 101, 167-169.

16. Jameson LJ, Ramadani N, Medlock JM, (2012). Possible drivers of Crimean-Congo hemorrhagic fever virus transmission in Kosova. Vector Borne Zoonotic Dis. 12, 753757.

17. Karti SS, Odabasi Z, Korten V, Yilmaz M, Sonmez M, Caylan R, Akdogan E, Eren N, Koksal I, Ovali E, Erickson BR, Vincent MJ, Nichol ST, Comer JA, Rollin PE, Ksiazek TG, (2004). Crimean-Congo Hemorrhagic Fever in Turkey. Emerg Infect Dis. 10, 1379-1384.

18. Kirbas A, Ozdemir H, Aksözek A, (2010). The investigation of Crimean-Congo Haemorrhagic fever virus infection se- roprevalance in cattle and sheep in Elazı $\breve{g}$, Samsun, Sivas, Tokat and Yozgat provinces. Firat Univ J Health Sci. 24, 137-142.

19. Leblebicioglu H, Ozaras R, Irmak H, Sencan I, (2016). Crimean-Congo hemorrhagic fever in Turkey: Current status and future challenges. Antiviral Res. 126, 21-34.

20. Lotfollahzadeh S, Nikbakht Boroujeni GR, Mokhber Dezfouli MR, Bokaei S, (2011). A serosurvey of CrimeanCongo haemorrhagic fever virus in dairy cattle in Iran. Zoonoses Public Health. 58, 54-59.

21. Lugaj A, Mertens M, Groschup MH, Bërxhol K, (2014). Serological Survey of CCHFV in Cattle in 10 Regions of Albania. Int J Res Applied, Nat Soc Sci. 2, 55-60.

22. Mertens M, Schuster I, Sas MA, Vatansever Z, Hubalek Z, Guven E, Deniz A, Georgiev G, Peshev R, Groschup MH, (2016). Crimean-Congo Hemorrhagic Fever Virus in Bulgaria and Turkey. Vector Borne Zoonotic Dis. 16, 619623.

23. Mertens M, Vatansever Z, Mrenoshki S, Krstevski K, Stefanovska J, Djadjovski I, Cvetkovikj I, Farkas R, Schuster I, Donnet F, Comtet L, Tordo N, Ben Mechlia M, Balkema-Buschmann A, Mitrov D, Groschup MH, (2015). Circulation of Crimean-Congo Hemorrhagic Fever Virus in the former Yugoslav Republic of Macedonia revealed by screening of cattle sera using a novel enzyme-linked immunosorbent assay. PLoS Negl Trop Dis. 9:e0003519.

24. Mourya DT, Yadav PD, Shete AM, Sathe PS, Sarkale PC, Pattnaik B, Sharma G, Upadhyay KJ, Gosavi S, Patil DY, Chaubal GY, Majumdar TD, Katoch VM, (2015). Crosssectional Serosurvey of Crimean-Congo Hemorrhagic Fever Virus IgG in Livestock, India, 2013-2014. Emerg Infect Dis. 21, 1837-1839.

25. Nalca A, Whitehouse CA, (2007). Crimean-Congo hemorrhagic fever virus infection among animals. Ergonul $\mathrm{O}$, Onder E, Whitehouse CA eds. Crimean-Congo Hemorrhagic Fever: A Global Perspective. Dordrecht, Netherlands: Springer. p.155-165.

26. Orkun Ö, Karaer Z, Çakmak A, Nalbantoğlu S, (2017). Crimean-Congo hemorrhagic fever virus in ticks in Turkey: A broad range tick surveillance study. Infect Genet Evol. 52, 59-66.

27. Ozturk SB, Kirdar S, Ertugrul MB, Turan C, Ture M, (2017). A New Endemic Province of Crimean-Congo Haemorrhagic Fever in Turkey: Aydin. Klimik Dergisi. 30, 9-14.

28. Schuster I, Mertens M, Köllner B, Korytář T, Keller M, Hammerschmidt B, Müller T, Tordo N, Marianneau P, Mroz C, Rissmann M, Stroh E, Dähnert L, Hammerschmidt F, Ulrich RG, Groschup MH, (2016). A competitive ELISA for species-independent detection of Crimean-Congo hemorrhagic fever virus specific antibodies. Antiviral Res. 134, 161-166.

29. Shepherd AJ, Swanepoel R, Leman PA, (1989). Antibody response in Crimean-Congo hemorrhagic fever. Rev Infect Dis. 11, 801-806.

30. Spengler JR, Bergeron É, Rollin PE, (2016). Seroepidemiological Studies of Crimean-Congo 
Hemorrhagic Fever Virus in Domestic and Wild Animals. PLoS Negl Trop Dis. 10:e0004210.

31. Spengler JR, Estrada-Peña A, Garrison AR, Schmaljohn C, Spiropoulou CF, Bergeron É, Bente DA, (2016). A chronological review of experimental infection studies of the role of wild animals and livestock in the maintenance and transmission of Crimean-Congo hemorrhagic fever virus. Antiviral Res. 135, 31-47.

32. Tonbak S, Aktas M, Altay K, Azkur AK, Kalkan A, Bolat Y, Dumanli N, Ozdarendeli A, (2006). Crimean-Congo hemorrhagic fever virus: genetic analysis and tick survey in Turkey. J Clin Microbiol. 44, 4120-4124.

33. Tuncer P, Yesilbag K, Alpay G, Dincer E, Girisgin AO, Aydin L, Uyar Y, Ozkul A, (2014). Crimean-Congo Hemorrhagic Fever infection in domestic animals in Marmara region, Western Turkey. Ankara Univ Vet Fak Derg. 61, 49-53.

34. Vatansever Z, Uzun R, Estrada-Peña A, Ergonul O, (2007). Crimean-Congo Hemorrhagic Fever in Turkey. Ergonul $\mathrm{O}$, Onder E, Whitehouse CA. eds. Crimean-Congo Hemorrhagic Fever: A Global Perspective. Dordrecht, Netherlands: Springer. p. 59-74.
35. Whitehouse CA, (2004). Crimean-Congo hemorrhagic fever. Antiviral Res. 64, 145-160.

36. Wölfel R, Paweska JT, Petersen N, Grobbelaar AA, Leman PA, Hewson R, Georges-Courbot MC, Papa A, Gunther S, Drosten C, (2007). Virus Detection and Monitoring of Viral Load in Crimean-Congo Hemorrhagic Fever Virus Patients. Emerg Infect Dis. 13, 1097-1100.

37. Yen YC, Kong LX, Lee L, Zhang YQ, Li F, Cai BJ, Gao SY, (1985). Characteristics of Crimean-Congo hemorrhagic fever virus (Xinjiang strain) in China. Am J Trop Med Hyg. 34, 1179-1182.

38. Yesilbag K, Aydin L, Dincer E, Alpay G, Girisgin AO, Tuncer P, Ozkul A, (2013). Tick survey and detection of Crimean-Congo hemorrhagic fever virus in tick species from a non-endemic area, South Marmara region, Turkey. Exp Appl Acarol. 60, 253-261.

39. Yilmaz GR, Buzgan T, Irmak H, Safran A, Uzun R, Cevik MA, Torunoglu MA, (2009). The epidemiology of Crimean-Congo hemorrhagic fever in Turkey, 2002-2007. Int J Infect Dis. 13, 380-386. 